\title{
ASSESSMENT OF ANTHROPIC SOURCES THROUGH Pb ISOTOPES IN SÃO DOMINGOS BASIN, RIO DE JANEIRO, BRAZIL
}

\author{
ARIADNE MARRA DE SOUZA ${ }^{1 *}$, MAURO CESAR GERALDES², ANDERSON COSTA DOS SANTOS ${ }^{2}$
}

1 Centro de Ciências Exatas, Naturais e da Saúde, Universidade Federal do Espírito Santo (UFES), Alto Universitário s/n, Caixa Postal 16, Alegre ES, Brazil. CEP 29500-000. Phone +55(28) 3552-8702. ariadne_marra@oi.com.br

2 Faculdade de Geologia, Universidade do Estado do Rio de Janeiro (UERJ), Rua São Francisco Xavier 524, $4^{\circ}$ Andar, Bloco A, Maracanã, Rio de Janeiro - RJ, Brazil. 20550-900. Phone: +55 (21) 2234-0636.mauro.geraldes@gmail.com, andcostasantos@gmail.com

*Corresponding author, ariadne_marra@oi.com.br

Received on 3 April 2017

Received in revised form on 4 August 2017

Accepted on 5 August 2017

Editor: Maria Virginia Alves Martins, Universidade do Estado do Rio de Janeiro, Brazil

\section{Abstract}

Sediments from São Domingos Basin were analyzed for $\mathrm{Pb}$ isotope composition aiming to characterize the contamination by metals, in an area of tomato production with intense use of pesticide. Located in the city of São José de Ubá, Rio de Janeiro State, Brazil, an important tomato producer, that basin is an environmental laboratory due to the crop activity. This work aims to trace the anthropic activity in the basin using $\mathrm{Pb}$ isotope composition and comparing the results with other similar works. Sampling was carried out using stream 23 bottom sediments samples. The 200 mesh $(0.075 \mathrm{~mm})$ fraction was leached (using $\mathrm{HNO}_{3}$ ) and residues were dissolved by HF. Samples were analyzed by two different mass spectrometer methods: leaching in ICP-MS, and leaching and residue in TIMS. For TIMS analysis, Pb was separated by ion exchange columns. The results define $\mathrm{Pb} / \mathrm{Pb}$ isotope signature groups interpreted as different sources of $\mathrm{Pb}$. The samples analyses yielded different $\mathrm{Pb}$ compositions, probably resulting from active pollutants which were transported by the rivers and provided by mixed sources. The ${ }^{206} \mathrm{~Pb} / 207 \mathrm{~Pb}$ ratios, applied in environmental studies, are used to trace pollution sources in this work. The results of ICP-MS and TIMS show ${ }^{206} \mathrm{~Pb} /{ }^{207} \mathrm{~Pb}$ values from 1.093 to 1.333 from leaching and 1.143 to 1.490 from residues. Each method has results that can be separated in two groups. The values from the first group are associated with gasoline and geogenic (Ribeira Belt Neoproterozoic rocks) sources and have the highest $\mathrm{Pb}$ concentration. The values of the second group may be interpreted as sewage and unidentified source, probably related to the pesticide used in the tomato crops, and have the lowest $\mathrm{Pb}$ concentration. Hence, gasoline and natural source are the main metal contributions. Both methods show similar values and complete each other; however, TIMS shows better precision than ICP-MS.

Keywords: Pb isotopes. Sediments. Environmental Quality Assessment. Pesticide. Pollution. 


\section{Introduction}

Lead is the most common heavy metal in the crust. It is a natural compound of rocks in galena and has wide industrial use. It does not have essential function in the human body and is extremely dangerous when absorbed (Barbosa Jr. et al., 2006). According to Paula and Geraldes (2005), in the last 6,000 years, natural and anthropogenic $\mathrm{Pb}$ has been introduced into the global environment by atmosphere. The authors noticed that the most anthropogenic lead released during industrial revolution was emitted solely as a by-product of mining and lead, silver and copper smelting.

In the mid- $18^{\text {th }}$ century, combustion of $\mathrm{Pb}$-containing coal became the primary source of industrial lead emissions in the atmosphere. After the 1920s, automobile exhaust system from $\mathrm{Pb}$-containing gasoline additives (alkyl lead) was higher than other anthropogenic $\mathrm{Pb}$ emission sources into the environment. More than $95 \%$ of present-day lead deposited in the environment are of anthropogenic origin (Marcantonio et al., 2002). Lead is associated with economic development occurred in different periods and with distinct features in countries; consequently, $\mathrm{Pb}$ isotopes record is geographic and time-dependent (Paula and Geraldes, 2005).

Total $\mathrm{Pb}$ concentrations alone may not be enough to separate pollution from natural background, since the background values of $\mathrm{Pb}$ concentration are highly variable because of natural processes and sources features (Helland et al., 2002). However, $\mathrm{Pb}$ isotope abundances are not affected by any measurable physical or chemical processes in environment. Indeed, isotopic differences in $\mathrm{Pb}$ emissions enable the use of historical records of anthropogenic $\mathrm{Pb}$ isotope variations and trace the changing sources of $\mathrm{Pb}$ pollutant over time (Paula and Geraldes, 2005; Komárek et al., 2008).

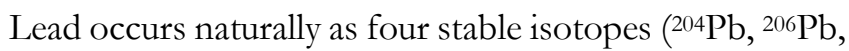
${ }^{207} \mathrm{~Pb}$ and ${ }^{208} \mathrm{~Pb}$ ) and is one of the highest contaminants in surface water, when it is strongly adsorbed to particles and typically to organic material of the soil. Pb isotopic analyses have been used to trace elements in recent sediments and to distinguish their sources, to track elements along their route until deposition and to assess the effect of remediation actions to reduce emissions from polluters (Marcantonio et al., 2002). Reference sites aiming to determine the baseline of ecosystems and information on background concentrations are important findings in the remediation of impacted areas (Paula and Geraldes, 2005).

Lead isotopes are powerful tracers of the origin and provenance of soils, lake sediments, coasts estuarine sediments and ice, and can distinguish contamination resulted from industrial activities (Komárek et al., 2008). The main $\mathrm{Pb}$ ratios used in environmental studies are ${ }^{206} \mathrm{~Pb} / 207 \mathrm{~Pb}$.

Nowadays, lead is present in many products: petroleum, industrial process, inks, water pipes, air, dust, soil, water, and pesticides. According to Spadotto et al. (2001), Brazil is among the largest consumers of pesticides in the world and has become an increasing consumer over the last thirty years. After absorption of pesticides by soil, several processes may affect physical, chemical and biological processes.

This work aims to apply $\mathrm{Pb}$ isotopes studies in sediments from São Domingos River located in the NW area of Rio de Janeiro State (Fig. 1), to discriminate the signature of metal contamination from domestic sewage, intensive tomato crops and geogenic sources. These $\mathrm{Pb}$ isotopes are found in food and water and/or groundwater near the plantations.

\subsection{São Domingos River Basin}

São Domingos River is located in São José de Ubá city and is a small tributary of Muriaé River. On the other hand, Muriaé River is an important part of the Paraíba do Sul Basin, one of the biggest and main rivers of Rio de Janeiro State, southeastern Brazil.

São José de Ubá region has been suffering an accelerated degradation of natural resources due to agriculture and inadequate soil management. Soils have a natural low rate of infiltration, impairing the recharge of groundwater reserves and causing the loss by runoff from a large part of rainwater, which results in flooding or drought depending on the season (Ferreira et al., 2005).

Metal contamination, including $\mathrm{Pb}$, can be provided by diffuse sources, such as vehicle exhaust emissions, or by local sources, such as sewage or mine waste tips. São Domingos Basin is influenced by domestic sewage and by pesticides due to tomatoes monoculture. The tomato crops lead to intensive use of chemicals, both pesticides and fertilizers (Thiollent and Silva, 2007). This causes damages to the environment and to the workers' health, mainly because of the climate (dry winter and rainy summer), which is responsible for producing dispersion in soil and water. On the other hand, the sanitary conditions are not adequate for human health and the locals use rivers as domestic sewage discharge, and groundwater as water supply.

Due to environmental damages, this basin has been used as natural laboratory for several studies (e.g. agronomy, botany and groundwater) and has been studied by several institutions such as Production Center of São José de Ubá, the Brazilian Agricultural Research Corporation (EMBRAPA) (Brandão et al., 2005) and several Brazilian 
universities. According to Brandão et al. (2005), about 27 chemical products are being used in tomato crops. Four out of those products have high toxic components. The $\mathrm{Pb}$ isotope data from natural environmental archives are useful not only for assessing background concentration and temporal trends but for identifying pollutant region sources. For these reasons, the sampling included streams in the aforesaid cities, crops and unchanged areas.

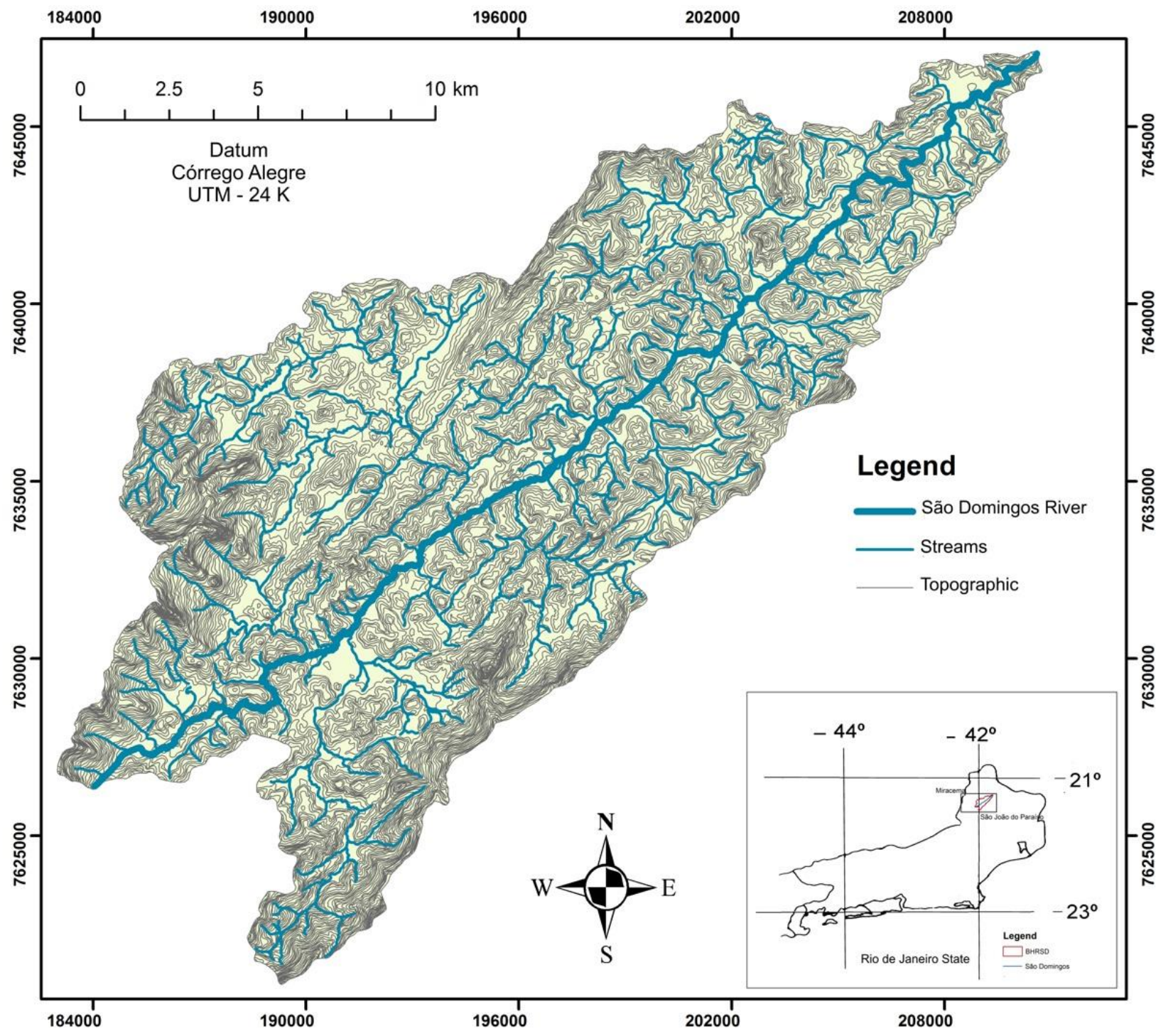

Fig. 1. São Domingos Basin location in Rio de Janeiro State (Brazil). Legend: BHRSD - Bacia Hidrográfica do Rio São Domingos - In Portuguese.

\section{Material and methods}

The samples were collected in the São Domingos stream and tributaries (Fig. 2), and analyzed by two different methods: ICP-MS and TIMS. Sample preparations methods included: 1) dry out; and 2) granulometric separations by dry sieving.
Twenty-four samples were analyzed by ICP-MS (18 samples) and TIMS (07 samples). Two of them, Pb03 and $\mathrm{Pb} 05$, were analyzed by both methods. Lead concentrations in the sediment fraction $<200$ mesh $(<0.075 \mathrm{~mm})$ are higher due to adsorption of organic material, Fe hydroxides, or precipitation such as sulphates or carbonates. For ICP-MS, 
the samples used were $\mathrm{Pb} 03, \mathrm{~Pb} 05$ and $\mathrm{Pb} 08-\mathrm{Pb} 26$. For TIMS analyses, $\mathrm{Pb} 01-\mathrm{Pb} 07$ were used. These samples were chosen because of their location in the basin, near tomato plantations.

As TIMS needs fewer amounts of samples, this method was used in samples with less fine particle fraction in the sifting procedure. ICP-MS, which has lower cost and displays simpler sample preparation, was used to analyze the other samples. The ICP-MS method also allows determining $\mathrm{Pb}$ concentration.

\subsection{ICP-MS (Inductively coupled plasma mass spectrometry)}

For ICP-MS, a leaching method was used based on SW 6010 EPA (Environment Pollution Agency-USA
Government) procedures, in which $10 \mathrm{~mL}$ of $\mathrm{HNO}_{3} 0.1 \%$ were added to $1 \mathrm{~g}$ of sediment. The sample was maintained at a temperature of $80^{\circ} \mathrm{C}$ for two hours.

Then the residue was discharged and the solution was analyzed. $\mathrm{Pb}$ analyses were carried out on a $\operatorname{Varian}{ }^{\circledR} 820-\mathrm{MS}$ and calibration with SRM 981 and SRM 982 standard from the National Institute of Standards and Technology (NIST, USA), and presented analytical error lower than $0.5 \%$. The isotope signature was determined at the Water Analyzes Laboratory, Pontifícia Universidade Católica, Rio de Janeiro (Pontifical Catholic University of Rio de Janeiro, PUC-RJ).

The total lead concentration was obtained by leaching solution and it was analyzed only by ICP-MS, which was calibrated by multi-elemental standard $3\left(10 \mathrm{mg} \cdot \mathrm{L}^{-1}\right)$ from Perkin Elmer ${ }^{\circledR}$.

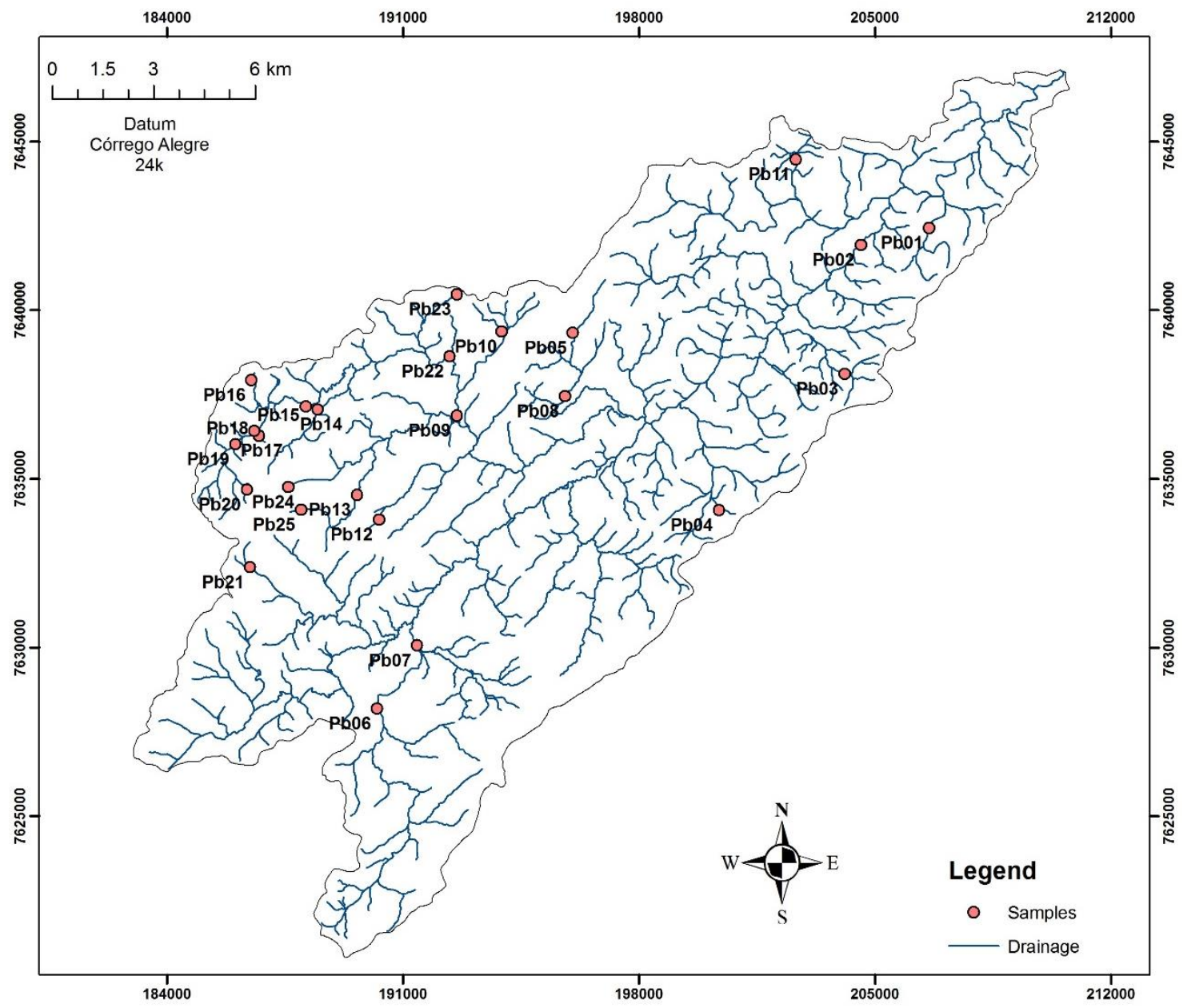

Fig. 2. Sampling distributions. 


\subsection{TIMS (Thermal Ionization Mass Spectrometry)}

TIMS was used according to the methodology described by Gioia et al. (2006): weighting and oxidation of organic material; leaching extraction procedures $\left(\mathrm{HNO}_{3}\right)$; residue total dissolution $(\mathrm{HF})$; and $\mathrm{Pb}$ isotope analysis obtained by TIMS $\left({ }^{207} \mathrm{~Pb} /{ }^{206} \mathrm{~Pb},{ }^{208} \mathrm{~Pb} /{ }^{204} \mathrm{~Pb},{ }^{207} \mathrm{~Pb} /{ }^{204} \mathrm{~Pb}\right.$, and ${ }^{206 \mathrm{~Pb} / 204} \mathrm{~Pb}$ ratios). The isotope signature was determined at the Isotope Geology Laboratory (LAGIR), Universidade do Estado do Rio de Janeiro (Rio de Janeiro State University - UERJ).

Leaching of $200 \mathrm{mg}$ of dry sediment begins in hot plate for $30 \mathrm{~min}$ at Savillex ${ }^{\circledR}$ beckers with $3 \mathrm{~mL}$ of $3.5 \mathrm{~N} \mathrm{HNO}_{3}+$ $3 \mathrm{~N} \mathrm{HCl}$. The residual phase was completely dissolved using the same procedure for the attack on the total sample. Total sample weighing 50-150 mg was dissolved in mixture of 2 $\mathrm{mL}$ of $6 \mathrm{~N} \mathrm{HCl}+(65 \%) \mathrm{HNO}_{3}$ for two days. The final solution was dried and dissolved with $6 \mathrm{~N} \mathrm{HCl}$.

Each sample was spiked with ${ }^{205} \mathrm{~Pb}(10-15 \mu \mathrm{l})$, and later evaporated and carried $0.6 \mathrm{~N} \mathrm{HBr}$; then $\mathrm{Pb}$ was extracted using columns stationed with anion exchange resin BioRad $\mathrm{X} 8$ in $0.6 \mathrm{~N} \mathrm{HBr}$, or alternatively, columns filled with $\mathrm{Sr}$ resin-spec.

The procedure used ultrapure reagents obtained by subboiling distillation in Teflon bottles. Separation of $\mathrm{Pb}$ consists of a single step, using anion exchange resin Biorad $(100 \mu \mathrm{l})$, polyethylene column $(5 \mathrm{~mm}$ in height and $4 \mathrm{~mm}$ internal diameter). The resin was cleaned by washing column with $1 \mathrm{~mL}$ of $6 \mathrm{~N} \mathrm{HCl}$, followed by $1 \mathrm{~mL}$ of $0.5 \mathrm{~N} \mathrm{HNO}_{3}$ and $1 \mathrm{~mL}$ of $\mathrm{H}_{2} \mathrm{O}$. The column was then conditioned with $0.4 \mathrm{~mL}$ $6 \mathrm{~N} \mathrm{HBr}$. The sample solution was brought up to the column and eluted with $3 \mathrm{~mL}$ of $0.6 \mathrm{~N} \mathrm{HBr}$. The fraction of $\mathrm{Pb}$ was extracted with $1 \mathrm{~mL}$ of $\mathrm{H}_{2} \mathrm{O}$ and dried on a hot plate. Samples were evaporated and loaded with phosphoric acid and silica gel onto the Re filament used in the mass spectrometer. The $\mathrm{Pb}$ analyses were carried out on a Triton Spectrometer with multicollector. The results were mass-corrected to the NBS981 standard.

\subsection{Data Processing}

Maps were prepared on ArcGis TM 10, using a cartographic base from the Instituto Brasileiro de Geografia e Estatística (Brazilian Institute of Geography and Statistics, IBGE) in "Córrego Alegre" Datum.
RESEARCH PAPER

The differentiation of groups was made by graphic way based on a scatter chart with results obtained by both methods (ICP-MS and TIMS), which enabled the definition of different groups of $\mathrm{Pb}$ isotope signature. The samples were separated in tow part and analyses to Isotopic Concentration (IC) and Isotopic Dilution (ID) and each one obtained values to leaching and residue.

\section{Results}

The eighteen samples analyzed by ICP-MS, using leaching procedure for obtaining total dissolution and isotopic signature of sediment samples, have $\mathrm{Pb}$ concentrations ranging from 0.858 to $0.203 \mathrm{mg} / \mathrm{kg}$ (Tab. 1), with a coefficient of variation of $44.32 \%$.

The results of ICP-MS isotopic signature ranged from 1.124 to 1.194 for ${ }^{206} \mathrm{~Pb} /{ }^{207} \mathrm{~Pb}$ ratio. IC was obtained by

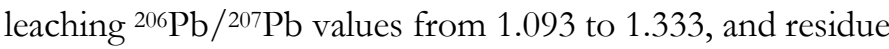
from 1.143 to 1.490 . On the other hand, ID was obtained by

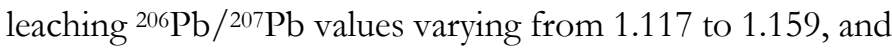
residue from 1.152 to 1.367 (Tab. 2).

The samples $\mathrm{Pb} 03$ and $\mathrm{Pb} 05$ yielded ${ }^{206 \mathrm{~Pb}} /{ }^{207} \mathrm{~Pb}$ values from 1.172 to 1.194 , and from 1.130 to 1.333 by ICP-MS and TIMS analyses. The coefficient variation among ICP-MS and TIMS ${ }^{206} \mathrm{~Pb} /{ }^{207} \mathrm{~Pb}$ values are 7.78 to sample $\mathrm{Pb} 03$ and 3.53 to sample $\mathrm{Pb} 05$.

Coefficient variation of TIMS IC and ID analyzes allow observing that values are quite variable; the higher variation is observed in ${ }^{208} \mathrm{~Pb} /{ }^{204} \mathrm{~Pb}$ ratio, from $6.06 \%$ to $27.64 \%$, and the least variation in ${ }^{207} \mathrm{~Pb} /{ }^{204} \mathrm{~Pb}$ ratio, from $0.71 \%$ to $5.27 \%$

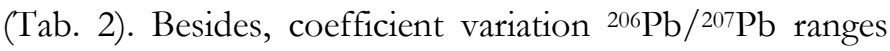
from $0.12 \%$ to $6.14 \%$ for residues, and from $0.98 \%$ to $11.10 \%$ for leaching.

For the purposes of comparison, the IC leaching data were used because these results have contrast values lower than ID values. IC results showed contrast average of $3 \%$ in the leaching and residue. In ID results, the contrast average values are 6\% in leaching and 5\% in residue. Sample $\mathrm{Pb} 06$ had the highest contrast in IC (26\%) and ID (16\%).

Two ${ }^{206} \mathrm{~Pb} /{ }^{207} \mathrm{~Pb}$ isotope signature groups were separated for each method. The isotope signature from ICP-MS ranged $\left(1^{\circ}\right)$ from 1.124 to 1.132 , and $\left(2^{\circ}\right)$ from 1.146 to 1.194 . These intervals were obtained by comparison among 
samples and defined by the biggest difference in sample values on a ${ }^{206} \mathrm{~Pb} /{ }^{204} \mathrm{~Pb} \mathrm{x}{ }^{207} \mathrm{~Pb} /{ }^{204} \mathrm{~Pb}$ graphic (Fig. 3).

The same parameter was used to separate two different groups on TIMS. IC leaching ranged from $\left(1^{\circ}\right) 1.093$ to 1.167, and $\left(2^{\circ}\right)$ from 1.232 to 1.333 ; and residue from $\left(1^{\circ}\right)$ 1.143 to 1.186; and $\left(2^{\circ}\right) 1.490$ (Fig. 4A and Fig. 4B). ID leaching varied from $\left(1^{\circ}\right) 1.117$ to 1.140 , and $\left(2^{\circ}\right) 1.143$ to
1.159; and residues from $\left(1^{\circ}\right) 1.152$ to 1.161 , and $\left(2^{\circ}\right) 1.213$ to 1.366 (Tab. 3). In Figure 5, the dots represent six concentration intervals. According to the map, the highest $\mathrm{Pb}$ concentration occurs in samples collected in north and northwest regions of the basin (Fig. 5). In the basin center, there is an urban area, where relatively high concentrations of $\mathrm{Pb}$ were also observed.

Tab. 1. Pb Concentrations and isotopic signature from ICP-MS.

\begin{tabular}{|c|c|c|c|c|c|}
\hline Samples & ${ }^{206} \mathbf{P b} /{ }^{207} \mathbf{P b}$ & ${ }^{206} \mathbf{P b} /{ }^{204} \mathbf{P b}$ & ${ }^{207} \mathbf{P b} /{ }^{204} \mathbf{P b}$ & ${ }^{208} \mathbf{P b} /{ }^{204} \mathbf{P b}$ & $\left.\mathbf{P b}_{\text {total }} \mathbf{( m g} / \mathbf{k g}\right)$ \\
\hline $\mathrm{Pb} 03$ & 1.194 & 19.179 & 16.061 & 39.438 & 0.316 \\
\hline $\mathrm{Pb} 5$ & 1.172 & 18.735 & 15.981 & 39.454 & 0.376 \\
\hline $\mathrm{Pb} 08$ & 1.156 & 18.238 & 15.778 & 38.781 & 0.845 \\
\hline $\mathrm{Pb} 09$ & 1.155 & 18.334 & 15.872 & 39.158 & 0.250 \\
\hline $\mathrm{Pb} 10$ & 1.146 & 18,140 & 15,831 & 39.436 & 0.219 \\
\hline $\mathrm{Pb} 11$ & 1.155 & 18.261 & 15.810 & 38.924 & 0.438 \\
\hline $\mathrm{Pb} 12$ & 1.125 & 17.637 & 15.674 & 38.673 & 0.758 \\
\hline $\mathrm{Pb} 13$ & 1.146 & 18.014 & 15.714 & 38.771 & 0.768 \\
\hline $\mathrm{Pb} 14$ & 1.125 & 17.761 & 15.786 & 38.695 & 0.858 \\
\hline $\mathrm{Pb} 15$ & 1.152 & 18.314 & 15.899 & 39.302 & 0.203 \\
\hline $\mathrm{Pb} 16$ & 1.160 & 18.374 & 15.840 & 39.452 & 0.464 \\
\hline $\mathrm{Pb} 17$ & 1.167 & 18.485 & 15.838 & 39.427 & 0.527 \\
\hline $\mathrm{Pb} 19$ & 1.135 & 17.874 & 15.741 & 38.831 & 0.455 \\
\hline $\mathrm{Pb} 20$ & 1.131 & 17.855 & 15.782 & 39.232 & 0.343 \\
\hline $\mathrm{Pb} 23$ & 1.130 & 17.773 & 15.729 & 39.050 & 0.743 \\
\hline $\mathrm{Pb} 24$ & 1.132 & 17.668 & 15.613 & 38.905 & 0.335 \\
\hline $\mathrm{Pb} 25$ & 1.124 & 17.551 & 15.613 & 38.547 & 0.796 \\
\hline $\mathrm{Pb} 26$ & 1.131 & 17.677 & 15.624 & 38.699 & 0.489 \\
\hline
\end{tabular}

\section{Discussion}

From both methods applied in this research, similar results were obtained, especially in samples $\mathrm{Pb} 03$ and $\mathrm{Pb} 05$, but there were small differences. However, by observing coefficient variation in TIMS results, it is possible to state that it is more precise than ICP-MS. This happens because sample preparation in TIMS allows separating only $\mathrm{Pb}$ ratios, while ICP-MS does not separate the elements. Consequently, interference may occur.

The ${ }^{206} \mathrm{~Pb} /{ }^{207} \mathrm{~Pb}$ values of samples analyzed by TIMS range, for the residue ID, from 1.152 to 1.367 and, for IC,

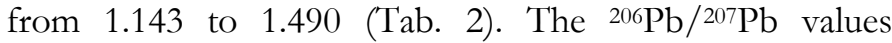
obtained by TIMS presented here can be compared to the anthropogenic signatures reported in other investigations in Brazil, mentioned in Figure 6 and discussed later. 
Tab. 2. Pb isotope results from TIMS.

\begin{tabular}{|c|c|c|c|c|c|c|}
\hline Method & Sample & Material & ${ }^{206} \mathrm{~Pb} /{ }^{204} \mathrm{~Pb}$ & ${ }^{206} \mathrm{~Pb} /{ }^{207} \mathrm{~Pb}$ & ${ }^{208} \mathrm{~Pb} /{ }^{204} \mathrm{~Pb}$ & ${ }^{207} \mathrm{~Pb} /{ }^{204} \mathrm{~Pb}$ \\
\hline \multirow{14}{*}{ 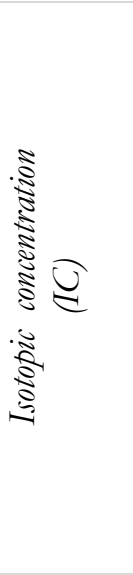 } & $\mathrm{Pb} 01$ & Residue & 18.096 & 1.158 & 38.646 & 15.632 \\
\hline & $\mathrm{Pb} 02$ & Residue & 17.794 & 1.143 & 38.000 & 15.562 \\
\hline & $\mathrm{Pb} 03$ & Residue & 18.640 & 1.186 & 38.895 & 15.713 \\
\hline & $\mathrm{Pb} 04$ & Residue & 18.017 & 1.155 & 38.383 & 15.605 \\
\hline & $\mathrm{Pb} 05$ & Residue & 18.413 & 1.176 & 38.764 & 15.652 \\
\hline & $\mathrm{Pb} 06$ & Residue & 23.993 & 1.490 & 69.933 & 16.103 \\
\hline & $\mathrm{Pb} 07$ & Residue & 18.037 & 1.157 & 38.341 & 15.588 \\
\hline & $\mathrm{Pb} 01$ & L1 & 19.422 & 1.236 & 50.454 & 15.712 \\
\hline & $\mathrm{Pb} 02$ & L1 & 18.013 & 1.159 & 38.682 & 15.547 \\
\hline & $\mathrm{Pb} 03$ & L1 & 21.242 & 1.333 & 49.905 & 15.938 \\
\hline & $\mathrm{Pb} 04$ & L1 & 18.249 & 1.167 & 39.937 & 15.634 \\
\hline & $\mathrm{Pb} 05$ & L1 & 19.435 & 1.232 & 43.049 & 15.774 \\
\hline & $\mathrm{Pb} 06$ & L1 & 16.937 & 1.093 & 36.696 & 15.492 \\
\hline & $\mathrm{Pb} 07$ & L1 & 17.021 & 1.093 & 36.905 & 15.571 \\
\hline \multirow{14}{*}{ 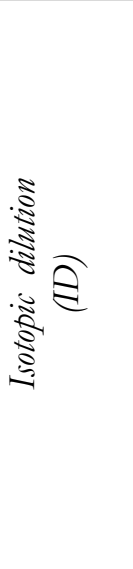 } & $\mathrm{Pb} 01$ & Residue & 19.332 & 1.227 & 42.563 & 15.758 \\
\hline & $\mathrm{Pb} 02$ & Residue & 18.103 & 1.160 & 38.455 & 15.606 \\
\hline & $\mathrm{Pb} 03$ & Residue & 20.796 & 1.313 & 50.346 & 15.841 \\
\hline & $\mathrm{Pb} 04$ & Residue & 17.961 & 1.153 & 39.308 & 15.578 \\
\hline & $\mathrm{Pb} 05$ & Residue & 19.022 & 1.212 & 46.139 & 15.695 \\
\hline & $\mathrm{Pb} 06$ & Residue & 21.636 & 1.366 & 64.200 & 15.842 \\
\hline & $\mathrm{Pb} 07$ & Residue & 17.982 & 1.152 & 38.183 & 15.608 \\
\hline & $\mathrm{Pb} 01$ & L1 & 17.998 & 1.159 & 38.868 & 15.523 \\
\hline & $\mathrm{Pb} 02$ & L1 & 17.750 & 1.143 & 38.602 & 15.536 \\
\hline & $\mathrm{Pb} 03$ & L1 & 17.667 & 1.139 & 37.971 & 15.514 \\
\hline & $\mathrm{Pb} 04$ & L1 & 17.779 & 1.136 & 38.157 & 15.662 \\
\hline & $\mathrm{Pb} 05$ & L1 & 17.515 & 1.130 & 35.796 & 15.499 \\
\hline & $\mathrm{Pb} 06$ & L1 & 17.750 & 1.140 & 38.097 & 15.564 \\
\hline & $\mathrm{Pb} 07$ & L1 & 19.967 & 1.117 & 43.532 & 17.759 \\
\hline
\end{tabular}

ICP-MS - Leaching

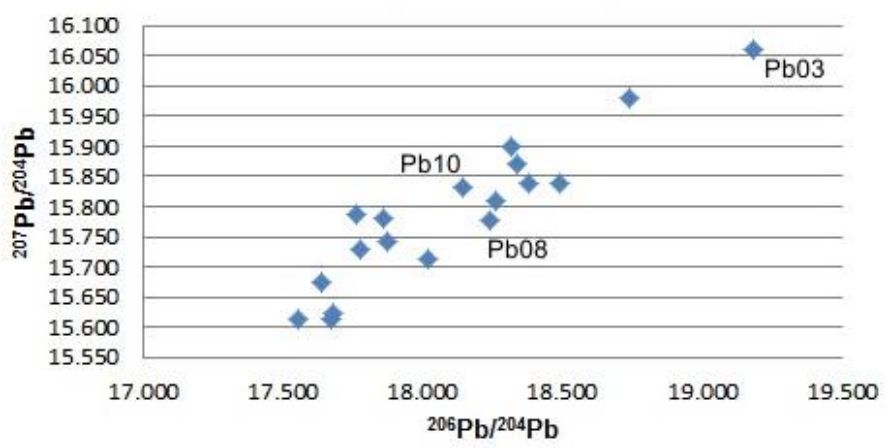

Fig. 3. Ratio ${ }^{206} \mathrm{~Pb} /{ }^{204} \mathrm{~Pb} \times{ }^{207} \mathrm{~Pb} /{ }^{204} \mathrm{~Pb}$ from ICP-MS leaching.

The northwest region of the basin shows the highest $\mathrm{Pb}$ concentration and is the area where tomato cropping is more intense. However, that area has isotope signature with value from the first ${ }^{206 \mathrm{~Pb} / 207} \mathrm{~Pb}$ isotope signature group of TIMS IC and ID residue, which ranged from 1.143 to 1.186 and 1.152 to 1.161 , respectively. This variation can be compared to the interval considered by Aily (2001), Bollhöfer et al. (1999) and Gioia et al. (2003) as an isotopic signature of fuel, in aerosol particles, which have been incorporated to the basin sediments by atmospheric fallout.

The second group of values ranges from ID 1.213 to 1.366 and IC 1.490 (the most radiogenic group). The $\mathrm{Pb}$ range from São Domingos Basin is similar to industrial waste $\mathrm{Pb}$ signature, as defined by Aily (2001). However, in the study area, there are not enough industries with polluted wastes to result in such high lead concentrations, since it is a rural area. The ${ }^{206 \mathrm{~Pb}} /{ }^{207} \mathrm{~Pb}$ residues from IC TIMS values are interpreted as geogenic (rock basement) signature (Fig. 6). 
Tab. 3. Radiogenic groups.

\begin{tabular}{|c|c|c|c|}
\hline Method & Equipment & Group & Range ${ }^{206} \mathrm{~Pb} /{ }^{207} \mathrm{~Pb}$ \\
\hline \multirow{6}{*}{ Leaching } & \multirow[t]{2}{*}{ ICP-MS } & $1^{\mathrm{o}}$ & 1.124 to 1.132 \\
\hline & & $2^{\circ}$ & 1.146 to 1.194 \\
\hline & \multirow[t]{2}{*}{ TIMS IC } & $1^{\circ}$ & 1.093 to 1.167 \\
\hline & & $2^{\circ}$ & 1.232 to 1.333 \\
\hline & \multirow[t]{2}{*}{ TIMS ID } & $1^{\circ}$ & 1.117 to 1.140 \\
\hline & & $2^{\circ}$ & 1.143 to 1.159 \\
\hline \multirow{4}{*}{ Residue } & \multirow[t]{2}{*}{ TIMS IC } & $1^{\circ}$ & 1.143 to 1.186 \\
\hline & & $2^{\circ}$ & 1.490 \\
\hline & \multirow[t]{2}{*}{ TIMS ID } & $1^{\circ}$ & 1.152 to 1.161 \\
\hline & & $2^{\circ}$ & 1.213 to 1.366 \\
\hline
\end{tabular}
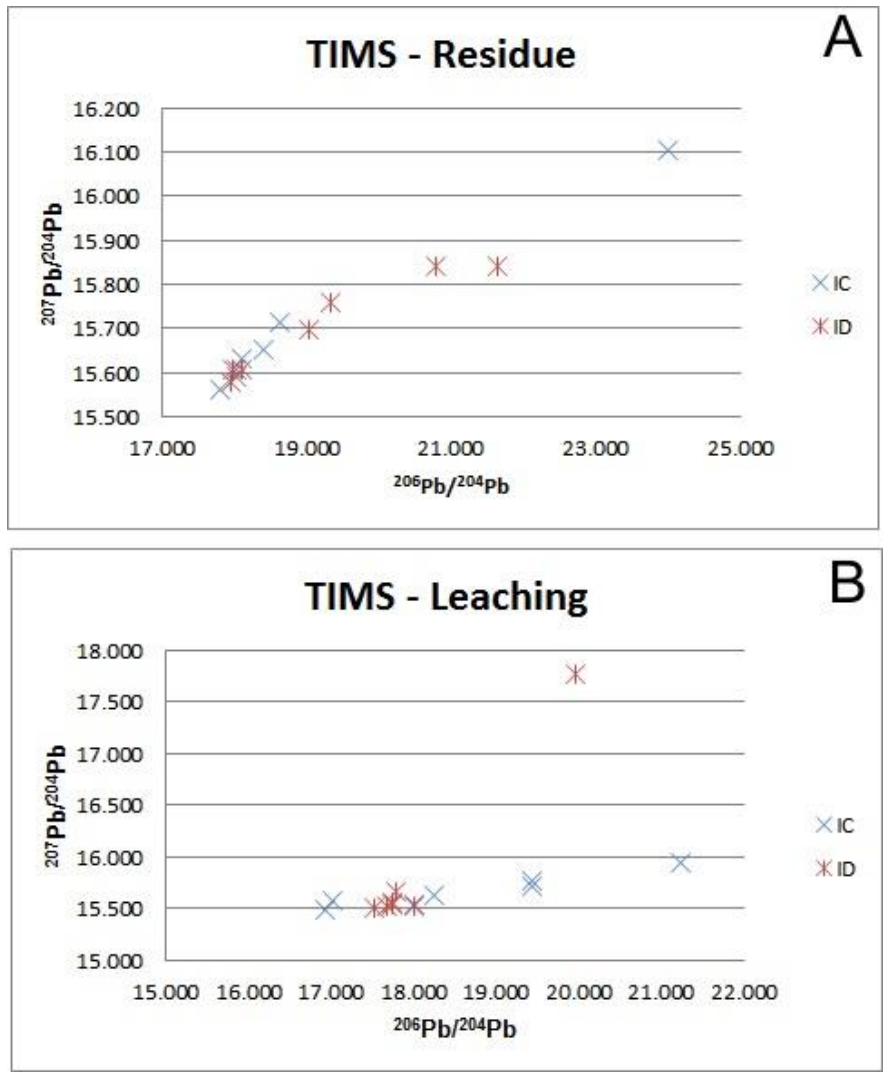

Fig. 4. Ratio ${ }^{206} \mathrm{~Pb} / 204 \mathrm{~Pb} \times{ }^{207} \mathrm{~Pb} / 204 \mathrm{~Pb}$ from A) TIMS Residue and B) TIMS Leaching

The leaching range has lower $\mathrm{Pb}$ concentrations than those associated with fuel source. For leaching from ICP-MS isotope analyses, two different ranges were found: one from 1.124 to 1.132 , and other from 1.146 to 1.194 . Both include less radiogenic TIMS range. The first should represent the uncompleted basement mixing with domestic sewage, is similar to the one measured in Guanabara Bay by Geraldes et al. (2006) and is related to several sources, especially domestic effluents. The second range can also be correlated to Aily (2001), Bollhöfer et al. (1999), Gioia et al. (2003), Moura et al. (2004) and Gioia et al. (2006), and may be associated with gasoline source and garbage.

The ${ }^{206} \mathrm{~Pb} /{ }^{207} \mathrm{~Pb}$ isotope signature residue values obtained by TIMS ranged from 1.152 to 1.161 . These values characterize anthropogenic sources and can be related to

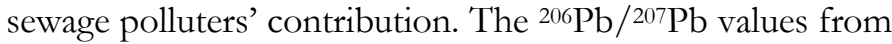
TIMS analyzer range from 1.213 to 1.366 , being higher (more radiogenic) than gasoline and domestic sewage values obtained in several studies in Brazil. On the other hand, these values are similar to those reported by Aily (2001) from industrial sources in São Paulo City and may be associated with pesticides used in tomato crops in São Domingos Basin.

Residue results analyzed by TIMS are similar to the second isotope signature group from ICP-MS leaching. This indicates that there is an important geogenic contribution mixed with anthropic source, considering that the residue also includes mineral composition. However, the first group 
is similar to ICP-MS and TIMS leaching results. The second group from TIMS residue is not comparable to other sources.

Studies using $\mathrm{Pb}$ isotope signatures of aerosols have been reported in South America. Bollhöfer and Rosman (2000) reported aerosol $\mathrm{Pb}$ signatures from Brazil (9 samples), Argentina (3 samples) and Chile (9 samples) and obtained ${ }^{206} \mathrm{~Pb} /{ }^{207} \mathrm{~Pb}$ values from 1.147 to 1.177 . Aily's (2001) study on the atmosphere $\mathrm{Pb}$ isotope composition performed in the São Paulo city, based on daily sampling during 14 months
(August 1999-September 2000), recorded ${ }^{206} \mathrm{~Pb} /{ }^{207} \mathrm{~Pb}$ values from 1.142 to 1.273 . These values are related to the contribution of $\mathrm{Pb}$-containing gasoline additives and industrial activities.

In addition, investigations on $\mathrm{Pb}$ isotopes analysis in mining waste (galena massive vein hosted in Neoproterozoic

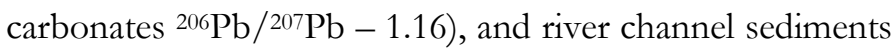
in a transect downstream $(206 \mathrm{~Pb} / 207 \mathrm{~Pb}-1.06$ to 1.11$)$ from the mines dump identified mining waste as the highest pollutant (Moraes et al. 2004).

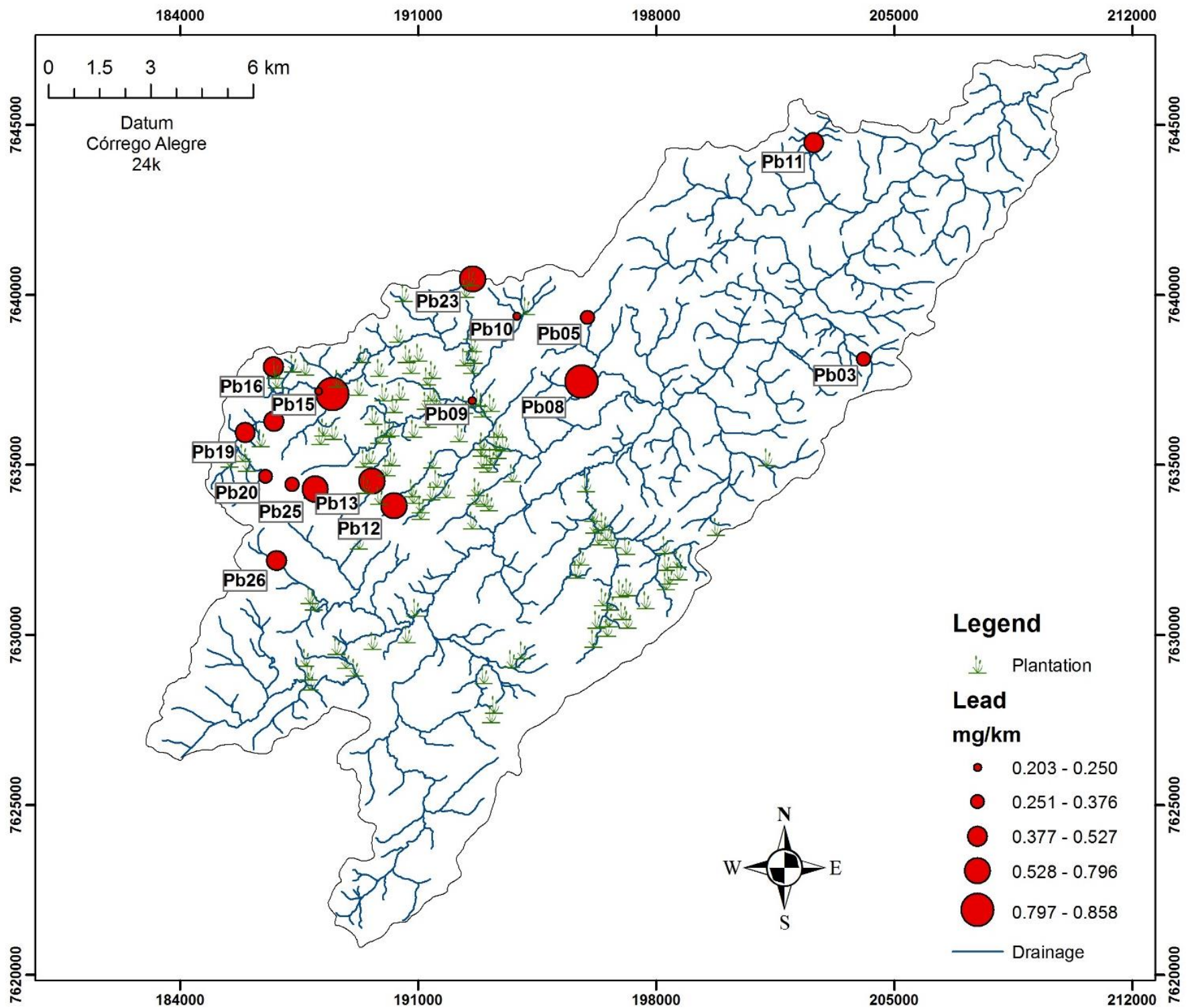

Fig. 5. Pb concentration map and tomato crops distribution of the São Domingos Basin. 
$\mathrm{Pb}$ isotope studies of sediments were also carried out in Brasilia (Distrito Federal-DF) and Belém (State of Pará), where ${ }^{206 \mathrm{~Pb}} /{ }^{207} \mathrm{~Pb}$ values ranged from 1.153 to 1.203 (Gioia et al., 2003), and from 1.162 to 1.203 (Moura et al., 2004), respectively.

$\mathrm{Pb}$ isotope data reported by Geraldes et al. (2006) in Guanabara Bay (Rio de Janeiro, Brazil), which receives different kind of industrial waste and domestic sewage, suggest that the sediments have a $\mathrm{Pb}$ signature $\left({ }^{206} \mathrm{~Pb} /{ }^{207} \mathrm{~Pb}\right.$ 1.14 to 1.18 range) similar to the one reported by Moraes et al. (2004).

These results can also be compared to those obtained by
Mirlean et al. (2005). The authors recorded ${ }^{206} \mathrm{~Pb} /{ }^{207} \mathrm{~Pb}$ ratio values from 1.169 to 1.131 in inks with different $\mathrm{Pb}$ concentrations used by fishermen in Rio Grande do Sul State, Brazil. They also obtained ${ }^{206} \mathrm{~Pb} /{ }^{207} \mathrm{~Pb}$ values from atmospheric aerosols in an area with human activity (1.108 to 1.149$)$.

The ink used in São José de Uba buildings does not get into direct contact with the local drainage; moreover, there are few constructed areas, so we can suggest that $\mathrm{Pb}$ isotope contamination from inks has no representation in the studied basin and is not a consistent source of lead. The town is also small and has no industrial activity.

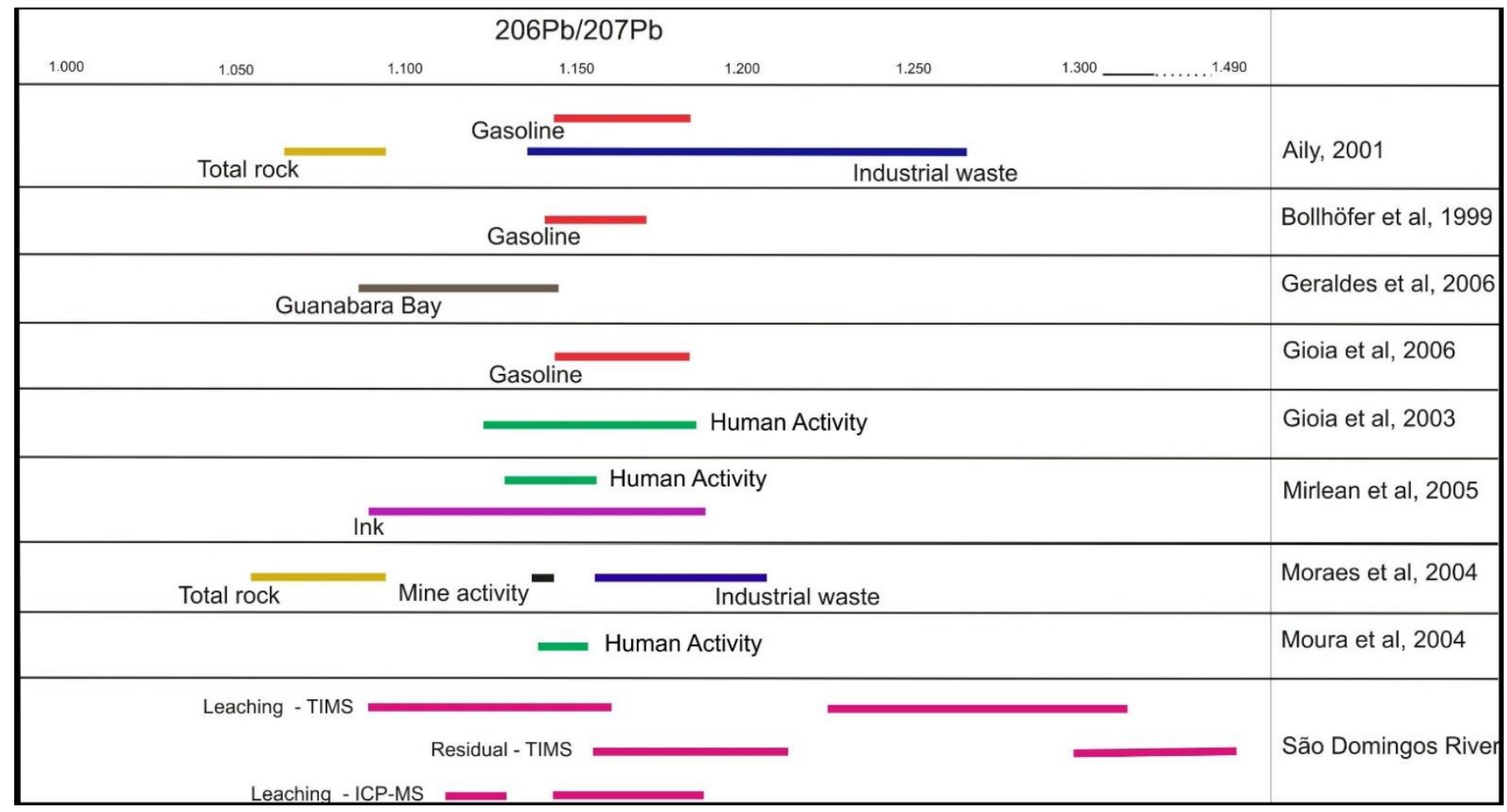

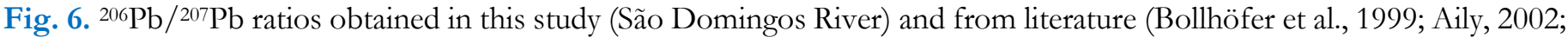
Gioia et al., 2003; Moraes et al., 2004; Moura et al., 2004; Mirlean et al., 2005; Geraldes et al., 2006 and; Gioia et al., 2006).

On the other hand, data obtained by Gioia et al. (2006) from sediments from Paranoá Lake in Brasilia (DF) indicate a less radiogenic signature of anthropogenic sources, covering the range from 1.15 to 1.17 in the ${ }^{206} \mathrm{~Pb} /{ }^{207} \mathrm{~Pb}$ ratio - the latter was associated with emissions from fossil fuels such as gasoline, among others.

The two ranges of $\mathrm{Pb}$ isotopic signatures observed in the ICP-MS analysis are the geogenic (basement rocks) and atmospheric (gasoline) sources. This study highlights the advantages of the systematic use of $\mathrm{Pb}$ isotopes to confirm the anthropic versus geogenic origins of this toxic heavy metal in recent sediments. However, this study has not identified so far other possible sources of contamination that would justify such results. Only the assessment of the isotopic signature of the pesticide used in the study area will be able to show if this is an important source of contamination. 


\section{Conclusion}

Based on the results of this work, the area is characterized by a mixing source of $\mathrm{Pb}$. There is human influence on $\mathrm{Pb}$ concentration and $\mathrm{Pb}$ isotopic signature, and an important geologic contribution as well. Further studies should be performed aiming to identify the anthropogenic sources of contamination.

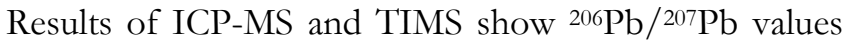
from 1.093 to 1.333 from leaching, and from 1.143 to 1.490 from residues in São Domingos Basin, separated in two groups that indicated different sources of metals for the basin. Four different sources of metals to the basin can be considered: geogenic source, domestic sewage, gasoline by atmospheric emissions, and a very radiogenic unidentified source, probably related to the use of pesticides.

Higher $\mathrm{Pb}$ concentrations are associated with less radiogenic samples, identified as geogenic source, so the pesticide influence is not the main metal source on the basin. The location of samples analyzed by TIMS can also affect the results meaning if different geology along the basin is considered.

Even if it could not be possible to identify significant difference between TIMS and ICP-MS methods, the analyses by both methods do not change the main isotopic interval and interpretation. Indeed, considering the coefficient variation, the TIMS-Isotopic concentration represents more precise results than those of ICP-MS.

\section{Acknowledgment \\ The authors would like to thank FINEP (Grant 3648/05), CNPq (Grant 471200/2003-4) and CNPq (Grant $501727 / 2005-1)$ for the financial support. The authors would also like to thank Gilberto Vaz and Carla Aguiar Neto for isotopic analyses.}

\section{References}

Aily, C., 2001. Caracterização isotópica de Pb na atmosfera: um exemplo da cidade de São Paulo. Dissertação de Mestrado. Instituto de Geociências. USP-São Paulo. 76p.

Barbosa Jr, F., Tanus-Santos, J.E., Gerlach, R.F., Parsons, P.J., 2006 A critical review of biomarkers used for monitoring human exposure to lead: advantages,
RESEARCH PAPER

limitations and future needs. Ciência \& Saúde Coletiva, Rio de Janeiro: ABRASCO 11 (1), 229-241.

Bollhöfer, A., Chisholm, W., Rosman, K.J.R., 1999. Sampling aerosols for lead isotopes on a global scale. Analytical Chimica 390, 227-235.

Bollhöfer A., Rosman, K.J.R., 2000. Isotopic source signatures for atmospheric lead: the Southern Hemisphere. Geochimica Cosmochimica Acta 64 (19), 3251-3262.

Brandão, E.S., Tôsto, S.G. Macedo, J.R. Costa, J.R.P.F. Bhering, S.B. Rangel, M. Marinho, A.G., 2005 - Análise Comparativa dos Custos de Produção de Tomate nos Sistemas Convencional e TOMATEC no Município de São José de Ubá. RJ. Embrapa - RJ.

Ferreira, R.C.C., La Terra, F.E., Menezes, T.L.P., Fontes, S.L., Roig, H.L., 2005. Prospecção Geoelétrica em Aqüíferos Fissurais. Estudo de Caso em São José do Ubá (RJ) In Ninth International Congress of the Brazilian Geophysical Society. Salvador.

Geraldes, M.C., Paula, A.H., Godoy, J.M., Valeriano, C.M., 2006. $\mathrm{Pb}$ isotope signatures of sediments from Guanabara Bay. SE Brazil: evidences for multiple anthropogenic sources. Journal of Geochemical Exploration 23, 122-126. doi.org/10.1016/j.gexplo. 2005.08.081

Gioia, S.M.C.L., Pimentel, M.M., Guimarães, E.M., Campos, J.E.L., Dantas, E.L., Maruoka, M.T.S., 2003. Atmospheric deposition and sources of anthropogenic lead in sediments from a recent lake in Brasilia. Central Brazil. IV South American Symposium on Isotope Geology. Short Papers 1, 434-437.

Gioia, S.M.C.L., Pimentel, M.M., Tessler, M., Dantas, E.L., Campos, J.E.G., Guimarães, E.M., Maruoka, M.T.S., Nascimento, E.L.C., 2006. Sources of anthropogenic lead in sediments from an artificial lake in Brasília - central Brazil. Science of the Total Environment 356, 125-142. doi: 10.1016/j.scitotenv.2005.02.041

Helland, A., Göran, A., Skei, J., 2002. Source dependent behaviour of lead and organic matter in the Glomma estuary. SE Norway: evidence from isotope ratios. Marine Chemistry 78,149-169. doi.org/10.1016/S03044203(02)00016-6

Komárek, M., Ettler, V., Chrastný, V., Mihaljevič, M., 2008. Lead isotopes in environmental sciences: A review. Environment International 34, 562-577. doi.org/10.1016/j.envint.2007.10.005

Marcantonio, F., Zimmerman, A. Xu, Y. Canuel, E., 2002. A $\mathrm{Pb}$ isotope record of mid-Atlantic US atmosphere $\mathrm{Pb}$ 
emissions in Chesapeake Bay sediments. Marine Chemistry 77, 123-132. doi.org/10.1016/S03044203(01)00081-0

Mirlean, N., Robinson, D., Kawashita, K., Vignol, M.L., Conceição, R., Chemale, F., 2005. Identification of local sources of lead in atmospheric deposits in an urban area in Southern Brazil using stable lead isotope ratios. Atmospheric Environment 39, 6204-6212. DOI: 10.1016/j.atmosenv.2005.07.002

Moraes, R.P., Figueiredo, B.R., Lafon, J.M., 2004. PbIsotopic tracing of metal-pollution sources in the Ribeira Valley. southeastern Brazil. Terrae. Campinas 1(1), 19-26.

Moura, C.A.V., Gaudette, H.E., Carvalho, M.C., Morales, G.P., 2004. The use of lead isotope composition as a tool to investigate the anthropogenic impacts on the environment in the metropolitan region of Belém (PA). TERRÆ 1(1), 16-25.

Paula, A.H., Geraldes, M.C., 2005. Holocene Pb isotope evolution: the record of the anthropogenic activity in the last 6,000 years. TERRÆ 2(1-2), 55-60.

Spadotto, C.A., Filizola, H., Gomes, M.A.F., 2001. Avaliação do Potencial de Lixiviação de Pesticidas em Latossolo da Região de Guaíra. SP. Pesticidas: R. Ecotoxicologia e Meio Ambiente, Curitiba 11.

Thiollent, M., Silva, G.O., 2007. Metodologia de pesquisaação na área de gestão de problemas ambientais. Reciis, Revista Eletrônica de Comunicação. Informação \& Inovação em Saúde, FioCruz, Rio de Janeiro 1(1), 93-100. 